Vol.45, Special n. : pp. 97-110, September 2002 ISSN 1516-8913 Printed in Brazil

\title{
Targeted Tumor Radiotherapy
}

\author{
Perihan Unak* \\ Ege University; Institute of Nuclear Sciences; Department of Nuclear Applications; 35100 Bornova Izmir Turkey; \\ unakp@bornova.ege.edu.tr
}

\begin{abstract}
Targeted tumor radiotherapy is selectively delivery of curative doses of radiation to malignant sites. The aim of the targeted tumor radiotherapy is to use the radionuclides which have high LET particle emissions conjugated to appropriate carrier molecules. The radionuclides are selectively collected by tumor cells, depositing lethal doses to tumor cells while no admission occur to normal cells.

In theory, targeted radiotherapy has several advantages over conventional radiotherapy since it allows a high radiation dose to be administered without causing normal tissue toxicity, although there are some limitations in the availability of appropriate targeting agents and in the calculations of administered doses. Therefore, for routine clinical applications more progress is still needed. In this article, the potential use of targeted tumor radiotherapy is briefly reviewed. More general aspects and considerations, such as potential radionuclides, mechanisms of tumor targeting was also outlined.
\end{abstract}

Key Words: Targeted Tumor Radiotherapy, radionuclide cancer therapy, high LET radiation, Auger electron radiotherapy

\section{INTRODUCTION}

Targeted tumor radiotherapy is a kind of radiation therapy that the radionuclides, which have high LET particle emissions conjugated to appropriate carrier molecules are selectively accumulated by tumor cells, depositing lethal doses to tumor cells while no admission occur to normal cells. To achieve this aim, radionuclides should have high LET particle emissions and they should be attached to appropriate carrier molecules which are selectively accumulated in tumor cells and deposits lethal doses to tumor cells while no admission occurs to normal cells in targeted tumor radiotherapy.

Targeted tumor radiotherapy have been firstly proposed by Regoud and Lacassagne in 1927
(Regoud and Lacassagne, 1927). They proposed that if the radionuclides deposited in cancer cells, this would be selectively curative in tumor cells. There are other synonyms related with targeted tumor radiotherapy such as targeted tumor therapy, radionuclide cancer therapy, combined chemo and radiotherapy of cancer. If the used ligand is an antibody, it is called radioimmunotherapy instead of targeted tumor radiotherapy. Radioimmunotherapy generally uses beta emitting radionuclides to kill the tumor cells. However, especially high energy beta emitters may not be efficient for micrometastases. For killing single cells, alpha emitting radionuclides or Auger nuclides, which have shorter ranged particles and higher LET may be more adequate. If alpha emitters were used as therapy radionuclide, alpha

\footnotetext{
* Author for correspondence
} 
immunotherapy term may be used instead of radioimmunotherapy in general term.

Development of a strategy for targeted tumor therapy has 2 limiting factors:

1. There must be less or not be incorporation in normal cells while radiopharmaceutical selectively incorporated into tumor cells in a high concentration.

2. Radionuclide must deposit all energy in tumor cells not in normal cells.

Radiopharmaceuticals deposition site in the cell is important factor to do a good selection of deposited radionuclides. For example, if deposition occurs in the cell nucleus, an Auger electron emitter radionuclide may be better to kill the cell, while in the case of cell surface deposition beta emitter may be preferable. Therefore, targeting mechanisms is also important in targeting tumor therapy. It may be attached a radionuclide into cell nucleus, or into cytoplasm or other parts of a cell by a proper ligand. Different nonhomogenous dose distributions can be achieved in each case.

\section{Potential radionuclides for Targeted Tumor Radiotherapy}

Table-1 shows some radionuclides, which have different decay characteristics, and emit particles with different LET and different range. Some of these radionuclides emit photons in addition to particle emission which make them suitable for monitoring the therapy with imaging, and for continuous follow-up of the absorbed dose distribution. Also, preadministration of the therapeutic ligands is possible in estimating the absorbed dose per unit administered activity. Where there is no emission of photons, bremstrahlung imaging might be a solution. Another solution is to label ligands with a gamma-emitting radionuclide with similar chemical properties, preferably an isotope of the same element as the therapeutic radionuclide or an isotope, which have similar chemical properties. Thus, gamma emitting radionuclide can be used for imaging and mechanisms of follow up, other one can be used for therapy. Tc $99 \mathrm{~m}$ and Re-186, Y-88 and Y-90, I-123 and I131, In-111 and $\mathrm{In}-114 \mathrm{~m}$ are this type of couples.

Table 1 - Physical Characteristics of Radionuclides that have potential for Targeted Tumor Radiotherapy

\begin{tabular}{cccc}
\hline Nuclide & Half-Life & Emission & Max Range \\
\hline${ }^{80 \mathrm{~m}} \mathrm{Br}$ & $4.42 \mathrm{~h}$ & Auger & $<10 \mathrm{~nm}$ \\
${ }^{125} \mathrm{I}$ & $60.0 \mathrm{~h}$ & Auger & $10 \mathrm{~nm}$ \\
${ }^{211} \mathrm{At}$ & $7.2 \mathrm{~h}$ & Alpha,Auger & $65 \mathrm{~nm}$ \\
${ }^{169} \mathrm{Er}$ & $9.5 \mathrm{~d}$ & Beta & $1 \mathrm{~mm}$ \\
${ }^{67} \mathrm{Cu}$ & $2.58 \mathrm{~d}$ & Beta/gamma & $2.2 \mathrm{~mm}$ \\
${ }^{131} \mathrm{I}$ & $8.04 \mathrm{~d}$ & Beta/gamma & $2.4 \mathrm{~mm}$ \\
${ }^{153} \mathrm{Sm}$ & $1.95 \mathrm{~d}$ & Beta/gamma & $3.0 \mathrm{~mm}$ \\
${ }^{198} \mathrm{Au}$ & $2.7 \mathrm{~d}$ & Beta/gamma & $4.4 \mathrm{~mm}$ \\
${ }^{186} \mathrm{Re}$ & $3.77 \mathrm{~d}$ & Beta/gamma & $5.0 \mathrm{~mm}$ \\
${ }^{165} \mathrm{Dy}$ & $2.33 \mathrm{~d}$ & Beta/gamma & $6.4 \mathrm{~mm}$ \\
${ }^{89} \mathrm{Sr}$ & $50.5 \mathrm{~d}$ & Beta & $8.0 \mathrm{~mm}$ \\
${ }^{32} \mathrm{P}$ & $14.3 \mathrm{~d}$ & Beta & $8.7 \mathrm{~mm}$ \\
${ }^{90} \mathrm{Y}$ & $2.67 \mathrm{~d}$ & Beta & $12 \mathrm{~mm}$ \\
\hline
\end{tabular}

Species of Ideal Radionuclides for Targeted Tumor Radiotherapy (Kairemo, 1996):

- The abundance of the electrons emitted by radionuclides should be lower than $40 \mathrm{keV}$.

- The photon emission to electron emission ratio should be lower than 2 .
- The half-life should be between $30 \mathrm{~min}$ and 10 days.

- The daughter nuclide should be stable or have a half-life longer than 60 days.

- It should be possible to produce the nuclides via neutron capture or proton -, deuteron-, ${ }^{3} \mathrm{He}-$ or $\alpha$-particle-induced reactions. 
- Their chemistry should be suitable for labeling reactions.

Decay path of the radionuclide that has a particular radiation is significant for a good targeting. Zalutsky was compared the ranges of some particular radiations with a cell size and reported that Y-90 beta particles have the range of 215 cells size, I-131 has 40 cells size and At-211 has only 3 cells size (Zalutsky \&Vaidyanathan, 2000). Therefore, At-211 is an appropriate radionuclide for single cell killing or micrometastases, others are better to destroy larger sized tumors or to label cell surface agents, like antibodies. At-211 is an attractive radionuclide for therapy. It decays by EC and alpha decay. Consequently it has both short ranged Auger electrons and alpha particles emissions, and is the heaviest member of halogens in periodic table. Therefore, its chemistry is similar to iodine. 6.3 Auger electrons and 1 alph a particle are emitted by At-211 per single decay (Spanek et al., 1996). I-125 is another interesting radionuclide. It decays by electron capture (EC) with a probability of $100 \%$, and then decays further by internal conversion (IC) with a probability of $93 \%$ to the stable tellurium-125 ground state. It is known as a very effective Auger electrons emitter, because of its specific decay characteristics. Thus, two successive Auger cascades occur per each decay of iodine -125 , and consequently it emits averagely 21 Auger electrons in condensed matters per decay. The energies of Auger electrons are between $10 \mathrm{eV}$ and $34 \mathrm{keV}$ (Charlton and Booz, 1981). It is also interesting to note that the ranges of Auger electrons emitted by an iodine -125 atom can be reached up to about $40-45 \mathrm{~nm}$, which is a significantly short range in condensed materials. This means that the local absorption of these Auger electrons results in high energy deposition in the decay vicinity of iodine -125 atom. The microdosimetric calculations have showed that Auger electrons have high LET radiation species like $\alpha$-radiations (Unak, 2000) and are more effective for micrometastases than beta rays (Ftachnikova and Bohm, 2000; Vandieren et al., 1994). Auger electrons are the orbital electrons released by atoms from which an inner shell orbital vacancy has been especially created by an electron capture process occurred in the atomic nucleus or by the internal conversion occurred by a low energy $\gamma$-radiation emitted by the nucleus, and/or following a photoelectric absorption of a low energy $\gamma$ - or $\mathrm{x}$ - ray by an inner shell electron of an atom. Fast Charge Neutralization after Auger cascade in the large biomolecules is one of the way to destroy the molecules especially in condensed phases (Halpern, 1990). I-124, another radionuclide with 4.2 days half-life, can be used for tumor therapy; it decays by $75 \% \mathrm{EC}$ and $25 \%$ positron emission. Also it may be used for PET although it is not commonly used yet (Eschman et al., 2002; Weinreich et al., 1998).

Cr-51, Ga-67, Br-77, Br-80m, In-111, Pt-193m, Pt-195m, Tl-201, At-211 are the other Auger electrons emitting radionuclides. The most well known of the Auger emitting radionuclides are the isotopes of iodine (I-123, I-124 and I-125) and bromine (Br-77 and $80 \mathrm{~m})$. To a much less degree, studies have been reported regarding Auger effects of In-111 and Pt-193m. Other Auger electron emitters, however, either have other emissions $(\gamma, \beta+, \beta-)$ or their half-lifes or production characteristics prevent their use. On the other hand, chemistry of halogens allow them to be more readily incorporated into organic molecules by traditional synthetic methods, whereas the metal ions require chelation techniques.

As a consequences, for an Auger electron emitting radiopharmaceutical to have thera peutic potential:

- A radionuclide must have an appropriate radiation decay profile,

- A radionuclide should be able to be economically prepared in reasonably high specific activity and purity,

- A radionuclide should be efficiently incorporated into a carrier molecule,

- A carrier molecule should display biodistributional selectivity for the target tissue.

- In the target tissue, the agent should associate with the DNA complex for a time consistent with the half-life of the radionuclide.

Low energy electrons like Auger electrons have important potentials for therapy of micrometastases since they have higher $\mathrm{S}$ values in cellular dimensions. Therefore, they have higher radiotoxicity in near surrounding area (Mattes, 2002). According to Mattes, the most potent of the Auger electron emitters are $\mathrm{Pt}-195 \mathrm{~m}$ which is approximately 10 -fold more potent than In-111. Sm-153 is attractive because it emits both abundant conversion electrons and moderate 
energy beta particles. At-211 is also an attractive radionuclide, it has highest S-values in cytoplasm and cell surface. (Mattes, 2002) (Table 2). Bernhardt reported that as the energy of electrons increased, absorbed dose rate decreases in small tumors (Bernhardt et al., 2001). This means that low energy electrons like Auger electr ons are more effective to cure metastases. On the other hand, if the photon emission to electron emission ratio is lower, tumor-to-normal-tissue dose rate is more effective. According to these considerations, while Y-90, I-131, In-111 which emit relatively higher beta energy electrons, are less effective in micrometastases, some of the others such as Co-58m, Os-189m, Rh-103m Sb-119, Ho-161, I125 are more effective to therapy in small tumors (Bernhardt et al., 2001). However, special carrier molecules, which can they selectively attach to tumor cells are required and carry off these radionuclides to tumor cells.

Table 2 - Cellular S Values for a Cell the Size of a Raji B-Lymphoma Cell (Mean cell diameter 15.4 $\mu$ m; mean nucleus diameter $12.3 \mu \mathrm{m})$ (Mattes, 2002)

\begin{tabular}{lccc}
\hline Radio Nuclide & Type of emitter & Cell Surface & $\begin{array}{c}10^{4} \text { xS-value (Gy/Bq.s) } \\
\text { Cytoplasm }\end{array}$ \\
\hline In-111 & Auger electron & 0.77 & 1.18 \\
I-125 & “ & 1.15 & 1.92 \\
Ga-67 & “ & 0.35 & 1.33 \\
Sm-153 & “ & 2.79 & 4.19 \\
Os-191 & “ & 5.59 & 9.33 \\
Pt-193m & “ & 2.00 & 5.44 \\
Pt-195m & “ & 7.59 & 13.30 \\
Hg-195m & $\beta$-particle & 4.33 & 8.41 \\
I-131 & $\beta$-particle & 1.06 & 1.54 \\
Y-90 & $\alpha$-particle & 0.48 & 0.68 \\
Bi-212 & $\alpha$-particle & 69.7 & 97.1 \\
At-211 & 81.6 & 114.0 \\
\hline
\end{tabular}

On the other hand, other important parameter to achieve effective doses is accumulated dose per unit time. Shorter half-life is an advantage to achieve to larger doses per unit time. In the case of I-125 labeling, 60 day half life of I-125 would not deliver enough decays to the target cells to effect therapy since the limited number of receptors which would be target for labeled molecule per cell, and the limited residence times for labeled molecules like ER receptors in target cells. However using I-123 labeled molecules, a nuclide whose $13.2 \mathrm{~h}$ half-life is more compatible with the usual residence times of labeled molecules in target cells. For example if the residence time is 2 hours in a receptors of a target cell, and if there are 1000 labeled molecules within target cell, in the case of I-125 labeling, only 1 decay occurs in 2 hours, but in the case of I-123 labeling, 100 decays occur in 2 hours.

\section{Targeting Mechanisms}

There are some of tumor seeking radiopharmaceuticals which may be used for different targeting mechanisms. If the targeting radionuclide is a low energy electron emitter like an Auger nuclide, of which the ranges are in molecular size, target should be inside the cell preferably in the cell nucleus. Therefore, the carrier molecule for the radionuclide has to cross the cell membrane either by passive diffusion or via a specific carrier mediated process. There are several mechanisms to carry out like nuclear receptor binding, DNA directed agents, other intracellular agents. For the treatment of cancers with targeted tumor radiotherapy, the most promising carrier molecules are estrogen receptor ligands, DNA directed agents (nucleosides, interchalators, groove binding), peptides and proteins.

\section{Estrogen Receptor Ligands}

Estrogen receptor is concentrated in the nucleus and when associated with estrogen in a high affinity complex, binds tightly to distinct sites in the DNA of responsive cells, the estrogen response 
elements, which are key to the estrogen induced regulation of specific gene expression.

Therefore, radiolabeled estrogen derivatives are the potential radiopharmaceuticals for targeted tumor radiotherapy. Several estra diol derivatives with high ER binding affinity have been investigated as potential breast cancer imaging agents or targeted therapy agents (DeSombre et al., 1988; DeSombre et al., 1990; DeSombre et al., 1992; Hughes et al., 1993; Rijks et al., 1997; Jonson et al., 1998; Skaddan et al., 1999; Skaddan et al., 2000; Hanson et al., 2000; Sasaki et al., 2000; Silva et al., 2001; Yasui et al., 1996).

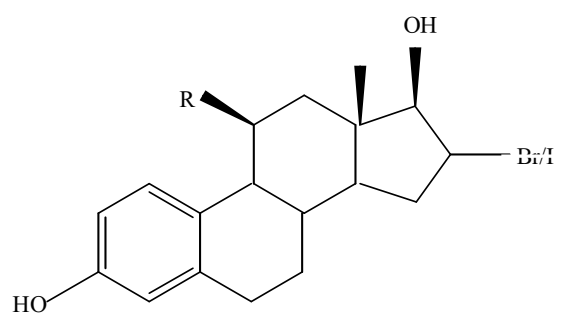

Figure 1 - 16 $\alpha-(\mathrm{IBr})$ Halogenated Estradiol

ER positive cells are present in many normal organs (e.g. uterus, ovaries, liver and pancreas) and neoplasms (e.g. breast, endometrial and ovarian cancers) (Delpassand et al., 1996; Nadal et al., 1998). Although estrogen derivatives proposed for generally breast and ovary, there are some reports indicating estrogen receptors in other tissues such as pancreas (Unak et al., 2002; Winborn et al., 1987).

Radiolabeling of estrogen compounds can have two aims; labeling with a diagnostic radionuclide such as ${ }^{99 \mathrm{~m}} \mathrm{Tc}$ for diagnostic aim, and labeling with therapeutical radionuclides such as ${ }^{186} \mathrm{Re}$ or ${ }^{188} \mathrm{Re}$ for therapeutic aim. Clearly, a radiolabeled estrogen derivative compound would be useful in diagnoses of the diseases that produce high levels of ERs, such as ovarian cancer, endometriosis, uterine carcinoma and meningioma. On the other hand, they may be good carrier molecules for tumor targeted radiotherapy since they are bound of the steroid-receptor complexes to the nuclear DNA (DeSombre et al., 1988; DeSombre et al., 1990; DeSombre et al., 1992; Hanson et al., 2000; Illidge et al., 2000; Mairs et al., 2000; Rijks et al., 1997).

\section{DNA directed agents}

Ertl and Feinendegen reported that I-125, when incorporated into the DNA in the form of thymidine precursor IUdR, was found to exhibit a far greater radiotoxicity than to be expected (Ertyl and Feinendegen, 1969). Considerable amount of work have been performed concerning single and double strand breaks and cell death concequences of I-125 and other Auger nuclides decay (Adelstein, 1992; Charlton et al., 1994; Geselowitz et al., 1995; Hofer et al., 1996; Hofer et al., 2000; Karaginnis et al., 2000; Lobachevsky and Martin, 2000; Schneiderman et al., 2001; Sedelnikova et al., 1998; Van Den Abbeele et al., 1992). IudR is an typical example to incorporate iodine radionuciides to DiNA in piace of thymidine. The size of methyi groun in 5 nosition is very simiiar with iodine thus these molecules are very similar each other (Fig. 2).

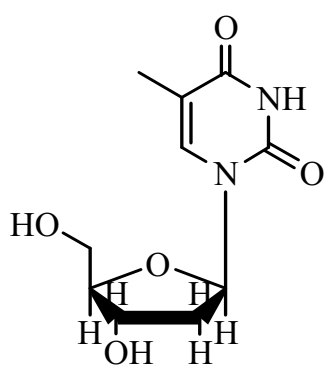

$\mathrm{r}_{\mathrm{CH} 3}=2.0 \AA^{\mathrm{Tdr}}$

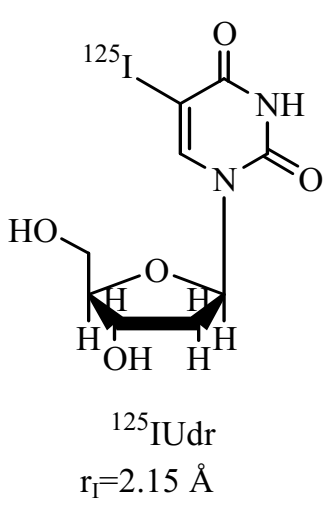

Figure 2 - Molecular structures of Thymidine and IUdR

Since the methyl group and iodine atom have similar Van der Waal radii, this substitution gives a compound that behaves remarkably like thymidine. Earlier studies have demonstrated substantial incorporation of radiolabelled IudR into DNA of tumor and proliferating tissues. As a thymidine analog, IudR is initially taken into cell, phosphorilated and incorporated in DNA, where it is retained by the cell or it's progency. Radiolabeled DNA, such as ${ }^{125} \mathrm{IUdR}$, has been used in-vitro for monitoring proliferation, migration and death of normal and neoplastic cell as well as for evaluation of the effectiveness of various chemotherapeutic or radiotherapeutic procedures (Charlton et al., 1994; Geselowitz et al., 1995; Hofer et al., 1996; Hofer et al., 2000; 
Kassis et al, 2000; Karaginnis et al., 2000; Lobachevsky and Martin, 2000; Schneiderman et al., 2001; Sedelnikova et al., 1998; Pomplun et al., 1992; Panyutin et al, 2001; Van Den Abbeele et al., 1992) and in animal tumor models (Kassis et al., 1996 a; Kassis et al.,1996b) and in cancer patients (Harrison et al, 1996; Mariani et al, 1993; 1994; 1996 a,b,c; Vandenabbeele et al., 1996). There are some reports indicating new intercalating agents to DNA, for example (I-125/I127) Ethidum (3,8-diamino-5-[6'-(piodobenzoylamino)-4'-azahexyl]-6-

phenylphenanthridinium chloride hydrochloride) was proposed as a intercalated ligand to DNA (Ho et al, 2001).

\section{Peptides and Proteins}

Peptides are important regulators of growth and cellular functions not only in normal ti ssues but also in tumors (Heppeler et al., 2000). Radionuclide labeled peptide molecules may be targeted for tumor therapies. Smaller size of peptide molecules according to larger proteins or antibodies supplies desirable pharmacokinetic properties, such as higher target to background ratios and faster blood clearance. A synthetic analog of somatostatin, octreotide has been used for several years as hormonal therapy in patient with carcinoid syndrome. I-123 (Kvols et al., 1993), Tc-99m (Maina et al., 1994), In-111, Y-90 (Jong et al., 1997), Y-86 (Rösch et al., 1999), Cu64 (Anderson et al., 1995) labeled derivatives of octreotide have been prepared and used used to image somatostatin receptor positive tumors in humans. Ga-68 (Froidevaux et al. 2002) and F-18 (Guhlke et al., 1994) labeled derivatives have been used for PET studies.

Other receptor expressing radiolabeled peptides were searched with the aim to develop radiopeptides for in vivo targeting such as $\alpha$ melanocyte-stimulating hormone ( $\alpha-\mathrm{MSH})$ (Bagutti et al., 1994; Bard, 1995), vasoactive intestinal peptide (VIP) (Rao et al, 2001; Thakur et al., 2000), substance P (SP) (Breeman et al., 1996), choleocystokinin-B (CCK-B) (Behr et al., 1999; Ertay et al., 2001), gastrin, neurotensin (NT) (Bergman et al., 2002; Garcia-Garayoa et al., 2001), bombesin (BN) (Breeman et al., 1999). They are all regulatory gut/brain peptides with multiple functions in the gastrointestinal tract and the central nervous system.

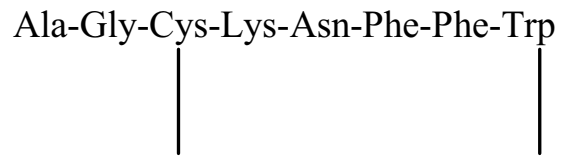

Cys-Ser-Thr-Phe-Thr-Lys

Somatostatin (SRIF)

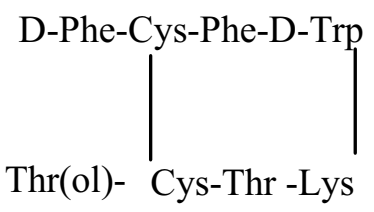

Octreotide (Sandostatin)

Figure 3 - Structural formulas of somatostatin (SRIF) and octreotide (Sandostatin ${ }^{\circledR}$ )

\section{Enzymatic Mechanisms}

Differential activation of tumor cells by labeled prodrugs can be achieved by some kind of enzymes. Some enzymatic activities are higher level in some tumor cells according to normal cells. The elevated activity of beta-glucuronidase in tumors has been a subject of several investigations. It is known that some tumors have higher enzyme glucuronidase activities (Unak, 2000). Radiolabeled Glucuronide derivatives of some radiotoxic agents can be good carriers for this kind of tumors. In this context, following criteria should be supplied in prodrug design (Unak, 2000):

- The prodrug must be considerably less toxic than its active form.

- The type of tumor investigated and be targeted by the prodrug must contain the activated enzyme, and this should be absent or in much lower concentration in all corresponding normal cells. The prodrug must be suitable substrate for the enzyme under physiolog ical conditions.

- The active form of prodrug must have a short biological half-life so that the toxic effects are limited to the tumor, selectively is not lost by its diffusion away from the tumor.

Aglycon which should be more toxic than glucuronide derivative is accumulated in the tumor cell after deglucuronidation and tumor cell is exposed by two kinds of toxicities; radiotoxicity 
comes from the proper radionuclide, and the chemical toxicity comes from the aglycon. Fishman reported first time human cancer tissues are relatively rich in $\beta$-glucuronidase (Fishman 1947, 1995). In 1974 Bicker reported that 8 hydroxyquinoline glucuronide accumulated three or four times higher in spindle-shaped sarcoma tumor according to normal tissues (Bicker, 1974). Antibody-directed enzyme prodrug therapy (ADEPT) is called the specific activation of a prodrug by an enzyme-immunoconjugate localized in tumor tissue. The use of an enzyme of human origin such as human $\beta$-glucuronidase is preferable in ADEPT because it might not be immunogenic when administered to patients. Houba et al synthesized four new glucuronide derivative of daunorubicin and investigated their usefulness in ADEPT (Houba et al., 1996). Wang et al proposed a glucuronide prodrug that can be enzymatically converted to an antineoplastic agent at tumor cells that are able to bind $\beta$ glucuronidase-monoclonal antibody conjugates. The glucuronide prodrug BHAMG, the tetra -nbutyl ammonium salt of (p-dichloroethylaminopheyl- $\beta$-glucopyranosid) uronic acid, was 150 times less toxic than the parent drug, $\mathrm{N}, \mathrm{N}$-di(2-chloroethyl)4-hydroxyaniline, toHepG2 human hepotoma cells and over 1000 fold less toxic than parent drug to AS-30D rat hepotoma cells in vitro (Wang et al., 1992). On the other hand, glucuronide derivatives of ceramide (Schmelz et al., 1999), dexamethasone (Haeberlin et al., 1993), retionoyl (Barua, 1997), have been proposed for the treatment of colon carsinogenesis. I-125 labeled derivatives of 8 -hydroxyquinoline glucuronide has also been reported (Unak and Unak, 1996; Unak and Unak 1997a).

1,4-Naphtoquinone diphosphonate (Synkavit) which is a vitamin K3 derivative is another compound selectively accumulate in certain tumors as a consequence of binding to the cell membrane associated alkaline phosphotase isoenzyme onco-APase (Andrews et al., 1962; Brown and Mitchell, 1979; Dendy, 1970; Zalutsky and Vaiyanathan, 2000) According to these authors, alkaline phosphotase dephosphorylates synkavit on the cell membrane, and the rest of the molecule incorporates into the cell. Labeled derivatives of synkavit with $\mathrm{H}-3$, I-131,I-125, Tc$99 \mathrm{~m}$ and At-211 derivatives have been reported (Andrews et al., 1962; Brown et al., 1982; Ercan et al., 1991; Ozdemir and Unak, 1994; Unak and Unak, 1993).

\section{Gene Therapy}

Gene therapy offers several approach to the treatment of cancer, including the introduction of genes that will encode for molecular targets not normally found in mammalian cells. The aim of gene therapy targeted to cancer cells is to introduce "suicide" genes, to transfer tumor suppressor genes, to inactivate aberrant oncogene expression, or to introduce genes encoding immunologically relevant molecules. Although no major successes have been reported, the positive results observed in some patients support the potential for gene therapy in the management of this disease.

A suicide gene is introduced to cancer cells selectively to tumor cells then a radiolabeled prodrug which is non-toxic to the normal cells but is toxic to tumor cells is administered in this therapy. The suicide proces s mostly is that based on the insertion of a viral kinase into the target tissue, which can then taken bioactivate a prodrug to a cytotoxic drug that kills the cell. A number of clinical trials around the world are based on the introduction of the Herpes Simplex virus (HSV) gene that encodes for viral thymidylate kinase (tk) (Lambrecht et al, 1998; Wiebe, 1998). Once the gene is expressed in the target (cancer) cells, 'suicide' therapy' can be effected simply by administering a selective, systemically non-toxic antiviral drug such as ganciclovir, that is highly toxic to the transected cells that can bioactivate it. In recent years, there are some achievements to combine with gene therapy with targeted tumor therapy which is called anti-gene radiotherapy. Panyutin et al. reported that double strand breaks (DSB) can be induced at certain appropriate triplex-forming oligonucleotides (TFO) and targets, frequencies approaching one DSB/decay, TFOs linked to Auger emitters can be highly effective mutagens for site-specific disruption of gene function. On the other hand, concerning the mechanisms of SSB repair indicate that nontargeted, non-DSB, Auger effect induced DNA damage would be efficiently repaired and relatively innocuous (Panyutin et al., 2000). 


\section{Dosimetry in Targeted Tumor Radiotherapy}

Since the biodistribution and pharmacokinetic of the radionuclides differ according to labeled molecule, dose calculations of radionuclide therapy is different from external therapy. On the other hand, dose distributions are not homogenous in radionuclide therapy since the range of particular radiations is too short, comparing external therapy beam. In contrast to modulation of external radiation beam geometry, the spatial dose distribution in radionuclide therapy can be modulated by selection of radiopharmaceuticals with varying pharmacokinetic (the carrier) and the radiation (the radionuclide) characteristics. Therefore, targeted tumor radiotherapy has an important potential in treatment planning for the induvidual patient. Unfortunately, internal radionuclide dosimetry has not reached yet to the state that radiation dosimetry has reached for external beam and sealed source because of its complexity.

Table 3 shows some of the radionuclides, which can be used for therapy. Some of the radionuclides such as Sc-47, Rh-105, In-111, I-123, I-131, Nd147, Pm-151, Sm-153, Ho-166, Gd-159,Tb-161, Er-171, Re-186, Re-188, Tl-201 have potentials in both therapy and diagnosis since they have appropriate decay characteristics for imaging and therapeutic studies. Although they have theoretical therapeutically potentials, In-111, I-123 and Tl201 are commonly used as diagnostic nuclides. Also Ho-166 has good decay characteristics for diagnostic purposes. Tl-201 is a remarkable radionuclide which is used for heart function studies. $44.78 \mathrm{keV}$ is emitted per decay. Approximately half of this energy is deposited in cellular range. Total emitting number is 20.68 and $0.073 \mathrm{gram}-\mathrm{rad} / \mathrm{microcurie}-$ hour is delivered in the cellular range (Rao et al., 1983; Unak, et al., 1997b). This amount is approximately 17 times higher comparing to Tc-99m cellular $\mathrm{S}$ value (Unak, et al., 1997b). Tl-201 has also been suggested for testicular imaging (Hosain et al., $1978)$ since a significant fraction $(0.15 \%)$ of $\mathrm{Tl}$ -
201 intravenously injected in humans is found in the gonads, where it has a long biological half-life. However, when Tl-201 concentrated in mouse testes, Auger electrons following electron capture decay are found to be much more effective in causing loss of testicular weight and reduction of sperm heads than the energetic beta particles from similarly distributed Tl-204 (Rao et al., 1983).

The selection of the optimal radionuclide may depend on the details of the clinical situation, such as the size and type of the tumor, and the particular carrier molecule to be used. Direct comparisons of various radionuclides are required to identify the optimal approach. However, to use of Auger and conversion electron emitters appears to have substantial advantages for single cell killing, in the therapy of micrometastases. Tumor therapy may require a mixture of radionuclides intended to kill both single cells and large tumor masses (Mattes, 2002). Auger and conversion electrons can kill cells effectively, with at least $6 \operatorname{logs}$ of cell. Conjugated ligands on the cell surface are only slightly less potent than carrier molecules internalized into the cytoplasm, and this is agree with theoretical considerations. $\alpha$-particles can kill single cells very effectively, but the short half lives of the available $\alpha$-particle emitters are probably a disadvantage. High energy $\beta$-particles can also kill single cells if they bind in sufficient amounts, but they have a disadvantage due to their nonspecific toxicity.

As a consequence, in order to perform targeted tumor radiotherapy.

It is required that:

- The radionuclides should have appropriate decay characteristics,

- Carrier molecules should be selective for tumor cells,

- Dosimetric and microdosimetric calculations should achieve appropriate doses to kill the tumor cells. 
Table 3 - Decay Mode of some selected radionuclides.

\begin{tabular}{llrcc}
\hline Radio Nuclide & \multicolumn{1}{c}{ Mode of Decay } & Half Life & Diagnosis & Therapy \\
\hline Sc-47 & $\beta \rightarrow \beta(162), \mathrm{CE}, \gamma(158)$ & $3.3 \mathrm{~d}$ & + & + \\
Cu-64 & $\beta, \mathrm{EC} \rightarrow \beta(71), \mathrm{CE}, \gamma(1345), \mathrm{X}$ & $13 \mathrm{~h}$ & - & + \\
Ga-67 & $\mathrm{EC} \rightarrow \gamma(185), \mathrm{CE}, \mathrm{X}, \mathrm{AE},(<10)$ & $3.3 \mathrm{~d}$ & + & - \\
Y-90 & $\beta \rightarrow \beta(935), \mathrm{X}$ & $2.7 \mathrm{~d}$ & - & + \\
Tc-99m & $\mathrm{IT} \rightarrow \gamma(142), \mathrm{CE}, \mathrm{X}, \mathrm{AE}(<20)$ & $6.0 \mathrm{~h}$ & + & - \\
Rh-105 & $\beta \rightarrow \beta(152), \mathrm{CE}, \gamma(319)$ & $1.5 \mathrm{~d}$ & + & + \\
In-111 & $\mathrm{EC} \rightarrow \gamma(245,171), \mathrm{CE} \mathrm{X}, \mathrm{AE}(<25)$ & $2.8 \mathrm{~d}$ & + & $+(?)$ \\
$\mathrm{I}-123$ & $\mathrm{EC} \rightarrow \gamma(159), \mathrm{CE}, \mathrm{X}, \mathrm{AE}(<30)$ & $13.2 \mathrm{~h}$ & + & $+(?)$ \\
$\mathrm{I}-125$ & $\mathrm{EC} \rightarrow \mathrm{CE}, \mathrm{X}, \mathrm{AE}(<30)$ & $60 \mathrm{~d}$ & - & + \\
$\mathrm{I}-131$ & $\beta \rightarrow \beta(182), \mathrm{CE}, \gamma(364), \mathrm{X}$ & $8.0 \mathrm{~d}$ & + & + \\
Pr-142 & $\beta \rightarrow \beta(809), \mathrm{CE}, \gamma(1575), \mathrm{X}, \mathrm{AE}$ & $19 \mathrm{~h}$ & - & + \\
Nd-147 & $\beta \rightarrow \beta(223), \mathrm{CE}, \gamma(103), \mathrm{X}, \mathrm{AE}(<40)$ & $11 \mathrm{~d}$ & + & + \\
Pm-151 & $\beta \rightarrow \beta(281), \mathrm{CE}, \gamma(168) \mathrm{X}, \mathrm{AE}$ & $1.2 \mathrm{~d}$ & + & + \\
Sm-153 & $\beta \rightarrow \beta(223), \mathrm{CE}, \gamma(103), \mathrm{X}, \mathrm{AE}$ & $2.0 \mathrm{~d}$ & + & + \\
Ho-166 & $\beta \rightarrow \beta(666), \mathrm{CE}, \gamma(80), \mathrm{X}, \mathrm{AE}(540,155)$ & $1.1 \mathrm{~d}$ & $+(?)$ & + \\
Gd-159 & $\beta \rightarrow \beta(305), \mathrm{CE}, \gamma(363), \mathrm{X}, \mathrm{AE}$ & $19 \mathrm{~h}$ & + & + \\
Tb-161 & $\beta \rightarrow \beta(115), \mathrm{CE}, \gamma(75), \mathrm{X}, \mathrm{AE}$ & $6.9 \mathrm{~h}$ & + & + \\
Er-171 & $\beta \rightarrow \beta(359), \mathrm{CE}, \gamma(308), \mathrm{X}, \mathrm{AE}$ & $7.5 \mathrm{~h}$ & + & + \\
Re-186 & $\beta, \mathrm{EC} \rightarrow \beta(349), \mathrm{CE}, \gamma(137), \mathrm{X}$ & $3.8 \mathrm{~d}$ & + & + \\
Re-188 & $\beta \rightarrow \beta(764), \mathrm{CE}, \gamma(137), \mathrm{X}$ & $17 \mathrm{~h}$ & + & + \\
Tl-201 & $\mathrm{EC} \rightarrow \gamma(167), \mathrm{CE} \mathrm{X}, \mathrm{AE}(<120)$ & $3 \mathrm{~d}$ & + & $+(?)$ \\
At-211 & $\mathrm{EC}, \alpha(5867), \mathrm{X}, \mathrm{AE}(<75)$ & $7.2 \mathrm{~h}$ & - & + \\
Bi-212 & $\beta, \alpha \rightarrow \alpha(5607,6090), \beta(459), \mathrm{CE}, \mathrm{AE}(<10)$ & 1.0 & - & + \\
\hline
\end{tabular}

\section{RESUMO}

A radioterapia tumor-seletiva é especialmente indicada na administração de doses curativas de radiação que interagem diretamente nas áreas de malignidade. O objetivo desta terapia tumoral direcionada é usar radionuclídeos que possuam emissão de partículas de elevado LET conjugadas à moléculas carreadoras apropriadas. Os radionuclídeos são seletivamente captados pelas células tumorais, liberando doses letais para as células tumorais enquanto não ocorre liberação para as células normais.

Em teoria, a radioterapia direcionada tem várias vantagens sobre a radioterapia convencional, pois permite que uma alta dose de radiação seja administrada sem causar toxicidade para o t ecido normal, embora existam algumas limitações na disponibilidade de agentes com alvos específicos e no cálculo da dose administrada. Consequentemente, para aplicações clínicas rotineiras é ainda necessário um maior progresso. Neste artigo, o uso potencial da radioterapia tumor-seletiva é brevemente revisto. Também resumiremos alguns aspectos e considerações mais gerais, tais como radionuclídeos potenciais e os mecanismos de direcionamento ao tumor.

\section{REFERENCES}

Adelstein, S. J. (1992), Biophysical aspects of Auger processes: A review of the literature, In- Biophysical Aspects of Auger Processes, eds. Howell, R. W. Narra, V. R. Sastry, K. S. R. Rao D. V. Am. Ass. Phys. In Med. Sym. Series, (8), 1-13.

Anderson, C. J.; Pejeu, T. S.; Edwards, B.; Sherman, E. L. C.; Rogers, B. E. and Welch, M. J. (1995), In Vitro and In Vivo Evaluation of Copper-64-Octreotide Conjugates, J. Nucl. Med., 36, 2315-2325.

Andrews, K. J. M.; Bultitude, F.; Evans, E. D.; Gronow, M.; Lambert, R. W. and Marrian, D. H. (1962), A radioactive drug 2-methyl-6-tritio-1,4naphthoquinon-bis(disodium phosphate) and 2methyl-5,6,7-tritio-1,4-naphthoquinol-bis(disodium phosphate), J. Chem. Soc., 3440-3450.

Bagutti, C.; Stolz, B.; Albert, R.; Bruns, C.; Pless, J. and Eberle, A. N. (1994), [In-111]-DTPA-Labeled Analogs of Alpha-Melanocyte-Stimulating Hormone for Melanoma Targeting-Receptor-Binding in-vitro and in-vivo, Int. J. Cancer, 58, 5, 749-755. 
Bard, D. R. (1995), An Improved Imaging Agent for Malignant-Melonoma, Based on [NLE (4), DPhe(7)]Alpha-Melanocyte Stimulating Hormone, Nucl. Med. Commun., 16 : (10), 860-866.

Barua, A. B. (1997), Retinoyl- $\beta$-D-glucuronide: A Biologically active form of vitamin A. Nutr. Rev., 55, 259-267.

Behr, T. M.; Jenner, N.; Behr, M.; Angerstein, C.; Gratz, S.; Raue, F. and Becker, W. (1999), Radiolabeled peptides for targeting CholecystokininB/Gastrin Receptor-Expressing tumors. J. Nucl. Med., 40, 1029-1044.

Benhard, P.; Forsell-Aronsson, E.; Jacobsson, L. and Skarnemak, G. (2001), Low-energy electron emitters for targeted radiotherapy of small tumors, Acta Oncologica, 40 : (5), 602-608.

Bergmann, R.; Scheunemann, M.; Heichert, C.; Mading, P.; Wittrisch, H.; Kretzschmar, M.; Rodig, H.; Tourwe, D.; Iterbeke, K.; Chavatte, K.; Zips, D.; Reubi, J. C. and Johannsen, B. (2002), Biodistribution and Catabolism of ${ }^{18} \mathrm{~F}$-labeled neurotensin(8-13), Analogs, Nucl. Med. Biol., 29, 61-72.

Bicker, U. (1974), Application of $\beta$-D-Glucuronides and Glucose together suggest a new direction for cancer chemotherapy. Nature, 252, 726-730.

Breeman, W. A. P.; VanHagen, M. P.; VisserWisselaar, H. A.; van der Plujim, M. E.; Koper, J. W.; SetyonoHan, B.; Bakker, W. H.; Kwekkebom, D. J.; Hazenberg, M. P.; Laberts, S. J. J.; Wisser, T. J. and Krennig, E. P. (1996), In vitro and in vivo Studies of Substance P Receptor Expressing in Rats with the new Analog [indium-111-DTPA-Arg(1)] substance P, J. Nucl. Med., 37 : (1), 108-117.

Breeman, W. A. P.; De Jong, M.; Bernard, B. F.; Kwekkeboom, D. J.; Srinivasan, A.; van der Pluijm, M. E.; Hofland, L. J.; Visser, T. J. and Krenning, E. P. (1999), Pre-clinical evaluation of [In-111-DTPAPro(1), Tyr(4)] bombesin, a new radioligand for bombesin-receptor scintigraphy. Int. J. Cancer, 83 : (5), 657-663.

Brown, I. and Mitchell, J. S. (1979), 6-(I-125)-2Methyl-1,4-naphthoquinon-bis(disodium phosphate): a new potential anti-tumor drug. J. Chem. Soc. Chem. Commun., 15, 659-665.

Brown, I (1982), 6-(I-125-iodo)-2-Methyl-1,4naphthoquinon-bis(dilithium phosphate): synthesis of high specific activity compound for anti-cancer therapy. Radiochem. Radioanal. Lett., 52, 283-290.

Charlton, D. E. and Booz, J. (1981), A Monte Carlo Treatment of the Decay of I-125, Radiat. Res., 87, $10-23$.

Charlton, D. E.; Hofer, K. G.; Vanloon, N. and Schneiderman, M. H. (1994), Double-strand Breaks fron I-125 Incorporated in the DNA and Cell-Death, Int. J. Radiat. Biol., 66 : (5), 437-440.
Delpassand, E. S.; Yang, D. J.; Wallace, S.; Cherif, A.; Quadri, S. M.; Price, J.; Joubert, A.; Inoue, T. and Podolof, D. A. (1996), Synthesis, Biodistribution, and Estrogen Receptor Scintigraphy of Indium-111Diethylenetriaminepentaacetic acid-Tamoxifen Analogue, J. Pharm. Sci., 85 : (6), 553-559.

Dendy, P. P.(1970), Further studies on the uptake of synkavit and a radioactive analogue into tumor cells in tissue culture. Br. J. Cancer, 24, 817-825.

DeSombre, E. R., Mease, R. C.; Hughes, A.; Harper, P. V.; Dejesus, O. T. and Friedman A. M. (1988), Bromine-80m-labeled Estrogens: Auger Electronemitting, Estrogen Receptor-directed Ligands with Potential for Therapy of Estrogen, Cancer Res., 48, 899-906.

DeSombre, E. R.; Hughes, A.; Mease, R. C. and Harper, P. V. (1990), Comparison of the Distribution of Bromine-77-Bromovinyl Steroidal and Triphenylethylene Estrogens in the Immature Rat, $J$. Nucl. Med., 31, 1534-1542.

DeSombre, E. R.; Shafii, B.; Hanson, R. N.; Kuivanen, P. C. and Hughes, A. (1992), Estrogen ReceptorDirected Radiotoxicity with Auger Electrons: Specificity and Mean Lethal Dose, Cancer Rec., 52, 5752-5758.

Ercan, M. T.; Durak, H. S.; Kitapci, M.; Caner, B. E. and Senekowitsch, R. (1991), Evaluation of ${ }^{99 m}$ TcLabelled Vitamin K4 as an Agent for Testicular Imaging, Nuklear Medizin, 30, 35-39.

Ertay, T.; Unak, P.; Bekis, R.; Yurt, F.; Biber, F. Z. and Durak, H. (2001), New Radiolabelled CCK-8 Analogues [Tc-99m-GH-CCK-8 and Tc-99m-DTPACCK-8]: Preparation and Biodistribution Studies in Rats and Rabbits, Nucl. Med. Biol., 28 : (6), 667-678.

Ertl, H. H. and Feinendegen, L. E. (1969), Microdosimetry of I-125 with reference to the Auger Effect. In- Ebert H. G. (Ed.) Proc. $2^{\text {nd }}$ Sym. Microdosimetry, Stresa Italy, EUR 4452,

Eschman, S. M.; Reischl, G.; Bilger, K.; Kupferschlager, J.; Thelen, M. H.; Dohmen, B. M.; Besenfelder, H. and Bares, R. (2002), Evaluation of dosimetry of radioiodine therapy in beningn and malignant throid disorders by means of iodine-124 and PET, Eur. J. Nucl. Med., 29, 760-767.

Fishman, W. H. and Anlyan, A. J. (1947), The presence of high $\beta$-glucuronidase activity in cancer tissue. J. Biol. Chem., 169, 449-450.

Fishman, W. H. (1995), Isozymes, Tumor markers and Oncodevelopmental Biology, Tumor Biol., 16, 394-402.

Froidevaux, S.; Eberle, A. N.; Christe, M.; Sumanovski, L.; Heppeler, A.; Schmitt, J. S.; Eisenwiener, K.; Beglinger, C. and Macke, H. R. (2002), Neuroendocrine Tumor Targeting: Study of Novel Gallium-Labeled Somatostatin Radiopeptides in a Rat Pancreatic Tumor Model, Int. J. Cancer, 98 : (6), 930-937. 
Ftacnikova, S. and Bohm, R. (2000), Monte Carlo Calculations of Energy Deposition on Cellular, Multicellular and Organ Level for Auger Emitters, Radiat. Protect. Dos., 92 : (4), 279-288.

Garcia-Garayoa, E.; Allemann-Tannahill, L.; Blauenstein, P.; Willmann, M.; Carrel-Remy, N.; Tourwe, D.; Iterbeke, K.; Conrath, P. A. and Schubieker, P. (2001), In vitro and in vivo Evaluation of New Radiolabelled Neurotensin(8-13) Analogues with High Affinity for NT1 Receptors, Nucl. Med. Biol., 28, 75-84.

Geselowitz, D. A.; McManaway, M. E.; Hofer, K. G. and Neumann, R. D. (1995), The Cytotoxicity of Decays of Tritium and I-125 Incorporated in DNA of Mammalian-Cells Implications for the Low-LET Dosimetry of Incorporated Nuclides, Radiat. Res., 142 : (3), 321-326.

Guhlke, S.; Wester, H. J.; Bruns, C. and Stocklin, G. (1994), 2-[F-18]Fluoropropionyl-(D)Phe(1))Octreotide, A Potential Radiopharmaceutical For Quantitative Somatostatin Receptor Imaging With Pet - Synthesis, Radiolabeling, in-Vitro Validation And Biodistribution in Mice, Nucl. Med. Biol., 21 : (6), 819-825.

Haeberlin, B.; Rubas, W.; Nolen, H. W. and Friend, D. R. (1993), In vitro evaluation of dexamethasone- $\beta$-Dglucuronide for colon-specific drug delivery, Pharmacol. Res., 10, 1553-1562.

Halpern, A. (1990), Intra- and Intermolecular Energy Transfer and Superexcitation in Post-Auger Processes, Radiochimica Acta, 50, 129-134.

Hanson, R. N. (2000), Synthesis of Auger Elecronelectron emitting Radiopharmaceuticals, Curr. Pharm. Res., 6, 1457-1468.

Harrison, K. A.; Dalrymple, G. V.; Baranowska Kortylewicz, J.; Holdeman, K. P.; Schneiderman, M. H.; Lieberman, R. P.; Sharp, J. G.; Cohen, S. M.; Leichner, P. K.; Augustine, S. C.; Tempero, M. A.; Taylor, R. J. and Chiou, R. K. (1996), Radiolabeled iododeoxyuridine: Safety evaluation, J. Nucl. Med., 37 : (4), S13-S16.

Heppeler, A.; Froidevaux, S.; Eberle, A. N. and Maecke, H. R. (2000), Receptor Targeting for Tumor Localization and Therapy with Radiopeptides, Curr. Med. Chem., 7, 971-994.

Ho, N. H.; Tumeh, P. C. and Kassis, A. I. (2001), Synthesis and biological studies of iodinated (I-125/I127) ethidium, Nucl. Med. Biol., 28 : (8), 983-990.

Hoefnagel, C. A. (1998), Radionuclide Cancer Therapy, Ann. Nucl. Med., 12 : (2), 61-70.

Hofer, K. G.; Lin, X. and Bao, S. P. (1996), DNA Damage, Micronucleus formation, and cell death from I-125 Decays in DNA, Acta Oncologica, 35 : (7), 825-832.

Hofer, K. G.; Lin, X. and Schneiderman, M. H. (2000), Paradoxial Effects of I-125 Decays in Parent and Daughter DNA: A New Target Model for Radiation Damage, Radiat. Res., 153 : (4), 428-435.
Hosain, F.; Hosain, P. and Spencer, R. P. (1978), Testicular Imaging with T-201 and Comparison with other radionuclides. J. Nucl. Med., 19, 720-721.

Houba, P. H. J.; Leenders, R. G. G.; Boven, E.; Scheeren, J. W.; Pinedo, H. M. and Haishma, H. J. (1996), Characterization of Novel Antracycline Prodrugs Activated by Human $\beta$-glucuronidase for Use in Antibody Directed Enzyme Prodrug Therapy. Biochem. Pharm. 52, 455-466.

Hughes, A.; Gatley, S. J. and Desombre, E. R. (1993), Comparison of the Distribution of Radioiodinated-E$17 \alpha$-Iodovinyl-11 $\beta$-Methoxyestradiol and 2-Iodo-1,1bis(4-Hydroxyphenylene Estrogens in the Immature Female Rat, J. Nucl. Med., 34, 272-280.

Illidge, T. M. and Brock, S. (2000), Radioimmunotherapy of cancer: Using monoclonal antibodies to target radiotherapy, Curr. Pharm. Des., 14 : (6), 1399-1418.

Jong, M.; Bakker, W. H.; Krennig, E. P. Breeman, W. A. P.; Plujim, M. E.; Bernard, B. F.; Visser, T. H.; Jerman, E.; Behe, M.; Powell, P. and Macke, H. R. (1997), Yttrium-90 and indium-11 Labelling, Receptor binding and Biodistribution of $\left[\mathrm{DOTA}^{\circ}\right.$, D$\mathrm{Phe}^{1}$, Thy $\left.{ }^{3}\right]$ Octreotide, A Promising Somatostatin Analogue for Radionuclide Therapy. Eur. J. Nucl. Med., 24, 368-371.

Jonson, S. D. and Welch, M. J. (1998), PET imaging of breast cancer with fluorine-18 radiolabeled estrogens and progestins, Quat. J. Nucl. Med., 42 : (1), 8-17.

Kairemo, K. J. A. (1996), Radioimmunotherapy of solid cancers, Acta Oncologica, 35 : (3), 343-355.

Karaginnis, T. C.; Lobachevsky, P. N. and Martin, R. F. (2000), Cytotoxicity of an I-125-labelled DNA Ligand, Acta Oncologica, 39 : (6), 681-685.

Kassis, A. I. And Adelstein, S. J. (1996a), Preclinical studies with radioiodeoxyuridine, J. Nucl. Med., 37 : (4), S10-S12.

Kassis, A. I.; Tumeh, S. S.; Wen, P. Y. C.; Braranowska Kortylewicz, J.; Vandenabbeele, A. D.; Zimmermann, R. E.; Carvalho, P. A.; Garada, B. M.; DeSisto, W. C.; Bailey, N. O.; Castronovo, F. P.; Mariani, G.; Black, P. M. and Adelstein, S. J. (1996b), Intratumoral administration of -[I-123]Iodo2'-Deoxyuridine in a patients with a brain tumor, J. Nucl. Med., 37 : (4), S19-S22.

Kassis, A. I.; Walicka, M. A. and Adelstein, S. J. (2000), Double-strand break yield following I-125 decay-Effects of DNA conformation, Acta Oncologica, 39 : (6), 721-726.

Kvols, L. K.; Brown, M. L.; O'connor, M. K.; Hung, J. C.; Hayostek, R. J.; Reubi, J. C. and Lamberts, S. W. J. (1993), Evaluation of a Radiolabeled Somatostatin Analog (I-123 Octreotide) in the Detection and Localization of Carcinoid and Islet Cell Tumors, Radiology, 187, 129-133. 
Lambrecht, R. M.; Staehler, P.; Kley, J.; Oberdorfer, F.; Spiegel, M.; Gross, C.; Graepler, F. T. C.; Gregor, M. and Lauer, U. [19--], Design of Radiopharceuticals for Monitoring Gene Transfer Therapy, Modern Trends in Radiopharmaceuticals for Diagnosis and Therapy, IAEA TECDOC-1029. pp.429-435.

Lobachevsky, P. N. and Martin, R. F. (2000), Iodine125 Decay in a synthetic oligodeoxynucleotide. II. The Role of Auger electron irradiation compared to charge neutralization in DNA breakage, Radiat. Res., 153 : (3), 271-278.

Maina, T.; Stolz, B.; Albert, R.; Bruns, C.; Koch, P. and Macke, H. (1994), Synthesis, Radiochemistry and Biological Evaluation of a new Somatoetatin Analogue (SDZ 219-387), Labelled with Tc-99m. Eur. J. Nucl. Med., 21, 437-444.

Mairs, R. J.; Cunningham, S. H.; Boyd, M. and Carlin, S. (2000), Applications of gene transfer to targeted radiotherapy, Curr. Pharm. Des., 6 : (14), 1419-1432.

Mariani, G.; Collechi, P.; Giulliani, L.; Braranowska Kortylewicz, J.; Diluca, L.; Vandenabbeele, A. D.; Salvadori, P. A.; Dicasso, S.; Adelstein, S. J.; Bevilacqua, G.; Kassis, A. I.; Meucci, G. and Viacava, P. (1993), Tumor targeting potential and Metabolism of 5-[I-125]Iodo-2'-Deoxyuridine injected intratumorally in patients with breast cancer, Breast Cancer: From Biology and Therapy. Annals of the New York Academy of Sciences, 698, 204-211.

Mariani, G.; Dicasso, S.; Volterrani, D.; Bararanowska Kortylewicz, J.; Distefano, R.; Ricci, S.; Bellina, C. R.; Diluca, L.; Buralli, S.; Falcone, A.; Salvadori, P.; Mosca, F.; Adelstein, S. J. and Kassis, A. I. (1994), Tumor targeting with 5-[I-123]Iodo-2'-Deoxyuridine infused intraarterially in colon-cancer patients with liver metastases, Clin. Res., 42 : (2), A129-A129.

Mariani, G.; Di Sacco, S.; Volterrani, D.; Diluca, L.; Buralli, S.; Distefano, R; Bararanowska Kortylewicz, J.; Bonora, D.; Matteuchi, F.; Ricci, S.; Bellina, C. R.; Falcone, A.; Salvadori, P.; Mosca, F.; Adelstein, S. J. and Kassis, A. I. (1996a), Tumor-targeting by intra-arterial infusion of 5-[I-123]Iodo-2'Deoxyuridine in patients with liver metastases from colorecteral cancer, J. Nucl. Med., 37 : (4), S22-S25.

Mariani, G.; Collecchi, P.; Baldarssarri, S.; Diluca, L.; Buralli, S.; Fontanini, G.; Bararanowska Kortylewicz, J.; Adelstein, S. J. and Kassis, A. I. (1996b), Tumor uptake and mitotic activity pattern of 5-[I-123]Iodo2'-Deoxyuridine after intravesical infusion in patients with bladder cancer, J. Nucl. Med., 37 : (4), S16-S19.

Mariani, G.; Di Sacco, S.; Bonini, R.; Diluca, L.; Buralli, S.; Bonora, D.; Ricci, S.; Braranowska Kortylewicz, J.; Falcone, A.; Salvadori, P.; Mosca, F.; Adelstein, S. J.; Falcone, A. and Kassis, A. I. (1996c), Biochemical modulation by 5-fluorouracil and 1-folinic acid of tumor uptake of intra-arterial 5[I-123]iodo-2'-deoxyuridine inpatients with liver metastases from colorecteral cancer, Acta Oncologica, 35 : (7), 941-945.
Mattes, M. (2002), Radionuclide-Antibody Conjugates for Single-Cell Cytotoxicity. Cancer, 94, 1215-1223.

Nadal, A.; Rovira, J. M.; Laribi, O.; Leon-Quinto, T.; Andreu, E.; Ripoll, C. and Soria, B. (1998), Rapid insulinotropic effect of 17 beta-estradiol via a plasma membrane receptor, FASEB J., 12 : (13), 1341-1348.

Ozdemir, D. and Unak, P. (1994), Study on labelling conditions of 125I-synkavit with iodogen method. $J$. Radioanal. Nucl. Chem. Lett., 187 : (4), 277-283.

Panyutin, I. G.; Winters, T. A.; Feinendegen, L. E. and Neuman, R. D. (2000), Development of DNA-based radiopharmaceuticals carring Auger-electron emitters for anti-gene radiotherapy, Q. J. Nucl. Med., 44, 256-267.

Panyutin, I. V.; Luu, A. N.; Panyutin, I. G. and Neuman, R. D. (2001), Strand Breaks in Whole Plasmid DNA Produced by the Decay of I-125 in a Triplex-Forming Oligonucleotide, Radiat. Res., 156 : (2), 158-166.

Pomplun, E.; Roch, M. and Terrsol, M. (1992), Simulation of Strand Break Induction by DNA Incorporated ${ }^{125} \mathrm{I}$, In- Biophysical Aspects of Auger Processes, eds. Howell, R. W. Narra, V. R. Sastry, K. S. R. Rao D. V. Am. Ass. Phys. Med. Sym. Series, (8), 137-152.

Rao, D. V.; Govelitz, G. F. and Sastry, S. R. (1983), Radiotoxicity of Thallium-201 in Mouse Testes: Inadequacy of Conventional Dosimetry. J. Nucl. Med., 24, 145-153.

Rao, P. S.; Thakur, M. L.; Pallela, V.; Reddy, K.; Li, H.; Sharma, S.; Pham, H. L.; Diggles, L.; Minami, C. and Marcus, C. S. (2001), Tc-99m Labeled VIP analog: Evaluation for Imaging Colorecteral Cancer. Nucl. Med. Biol., 28 : (4), 445-450.

Regaud, C. And Lacassagne, A. (1927), La radiosensibilite cellulaire envisage dans ses manifestations generalis. In- Radiophysiologie et radiotherapie, Paris. Archieves de L'Institut du Radium de L'Universite de Paris and La Foundation Curie. pp. 95-116.

Rijks, L. J. M.; Bakker, P. J. M.; Vantienhoven, G.; Boer, G. J.; Rietbroek, R. C.; Taat, C. W.; Janssen, A. G. M.; Veendof, C. H. N. and Vanroyen, E. A. (1997), Imaging of estrogen receptors in primary and metastatic breast cancer patients with iodine-123labeled Z-MIVE, J. Clin. Oncol., 15 : (7), 2536-2545.

Rösch, F.; Herzog, H.; Stolz, B.; Brockmann, J.; Köhle, M.; Mühlensiepen, H.; Marbach, P. and MüllerGartner, H.W. (1999), Uptake Kinetics of the Somatostatin Receptor Ligand $\left[{ }^{86} \mathrm{Y}\right]$ DOTA-dPhe1TYr3-octreotide ([${ }^{86}$ Y]SMT487) using Positron Emission Tomography in Non-human Primates and Calculation of Radiation Doses of the 90Y-Labelled Analogue, Eur. J. Nucl. Med., 26, 358-366. 
Sasaki, M.; Fukumura, T.; Kuwabara, Y.; Yoshida, T.; Nakagawa, M.; Ichiya, Y. and Masuda, K. (2000), Biodistribution and breast tumor uptake of 16 alpha[F-18]-fluoro-17 beta-estradiol in rat, Ann. Nucl. Med., 14 : (2), 127-130.

Schmelz, E. M.; Bushnev, A. S.; Dillehay, D. L.; Sullards, M. C.; Liotta, D. C. and Merrill, A. H. (1999), Ceramide-beta-D-glucuronide: Synthesis, digestion, and suppression of early markers of colon carcinogenesis, Cancer Res., 59 : (22), 5768-5772.

Schneiderman, M. H.; Hofer, K. G. and Schneiderman, G. S. (2001), Targets for Radiation-induced Cell Death: When DNA Damage Doesn't Kill ? Radiat. Res., 155 : (4), 529-535.

Sedelnikova, O. A.; Panyutin, I. G.; Thierry, A. R. and Neuman, R. D. (1998), Radiotoxicity of Iodine-125 Labeled Oligodeoxyribonucleotides in Mammalian Cells, J. Nucl. Med., 39 : (8), 1412-1418.

Silva, M. C.; Lucianaa, P.; Gano, L.; Sá e Melo, M. L.; Inohae, E.; Shuntaroc, M. and Thiemann T. (2001), Synthesis and biological evaluation of two new radiolabelled estrogens:[125I](E)-3-methoxy-17aiodovinylestra-1,3,5(10),6-tetraen-17b-ol and [125I](Z)-3-methoxy-17a-iodovinylestra-1,3,5(10),6tetraen-17b-ol, Appl. Radiat. Isot., 54 : (2), 227-239.

Skaddan, M. B.; Wüst, F. R. and Katzenellenbogen, J. A. (1999), Synthesis and binding affinities of novel re-containing 7 alpha-substituted estradiol complexes: Models for breast cancer imaging agents, J. Org. Chem., 64 : (22), 8108-8121.

Skaddan, M. B.; Wüst, F. R.; Jonson, S.; Syhre, R.; Welch, M. J.; Spies, H. and Katzenellenbogen, J. A. (2000), Radiochemical synthesis and tissue distribution of Tc-99m-labeled $7 \boldsymbol{\alpha}$-substituted estradiol complexes, Nucl. Med. Biol., 27 : (3), 269-278.

Spanek, J.; Larsson, B. and Weinreich, R. (1996), Auger Electron Spectra of Radionuclides for Therapy and Diagnostics, Acta Oncologica, 35 : (7), 863-868.

Thakur, M. L.; Marcus, C. S.; Saeed, S.; Pallela, V.; Minami, C.; Diggles, L.; Le Pham, H.; Ahdoot, R. and Kalinowski, E. A. (2000), Tc-99m labeled Vaasoactive Intestinal Peptide Analog for Rapid Localizxation of Tumors in Humans, J. Nucl. Med., 41 : (1), 107-110.

Unak, T. and Unak, P. (1993), Synkavit and Its Direct Labelling with Iodine-125, as a potential Anti-tumor Drug., Nucl. Med. and Biol., 20 : (7), 889-894.

Unak, T. and Unak, P. (1996), Direct radioiodination of metabolic 8-hydroxyquinolyl-glucuronide, as a potential anti-cancer drug, Appl. Rad. Isot., 47 : (7), 645-647.

Unak, T.; Unak, P. and Ongun B. (1997a), Synthesis and iodine-125 labelling of glucuronide compounds for combined chemo- and radiotherapy of cancer, Appl. Radiat. Isot., 48 : (6), 777-783.
Unak, P.; Ipek, I. and Unak, T. (1997b), Microdosimetry of Auger and Conversion Electrons of ${ }^{201} \mathrm{Tl},{ }^{51} \mathrm{Cr},{ }^{55} \mathrm{Fe},{ }^{99 \mathrm{~m}} \mathrm{Tc}$ and Beta-Rays of ${ }^{204} \mathrm{Tl}$ at the Cellular Level, Physica Medica, 13 : (Suppl. 1), 166-168.

Unak, T. (2000), Potential Use of Radiolabeled Glucuronide Prodrugs with Auger and/or Alpha Emitters in Combined Chemo- and Radiotherapy of Cancer, Curr. Pharm. Des., 6, 1127-1142.

Unak, P.; Enginar, H.; Yurt, F.; Biber, F. Z.; Aslani, M. and Ozkilic, H. (2002), A Correlative Study Between 99mTc-ESTCPTA and ${ }^{99 \mathrm{~m}}$ Tc-MIBI in Rat, Appl. Radiat. Isot. [in press].

Vandenabbeele, A. D.; Bararanowska Kortylewicz, J.; Adelstein, S. J.; Carvalho, P. A.; Tutrone, R. F.; Richie, J. P.; Wen, P. Y. C.; Black, P.; McL. Marriani, G. and Kassis, A. I. (1992), Diagnostic and Therapeutical Applications of Auger Electron Emitting 5-[ $\left.{ }^{123} \mathrm{I} /{ }^{125} \mathrm{I}\right]$ Iodo-2'-deoxyuridine in Cancer, In- Howell, R. W.; Narra, V. R.; Sastry, K. S. R. and Rao, D. V. (eds.). Biological Aspects of Auger Processes. Am. Ass. Phys. In Med., Sym. Prooceed., (8), 372-395.

Vandenabbeele, A. D.; Tutrone, R. F.; Berman, R. M.; Bararanowska Kortylewicz, J.; Barclay, P. D.; Richie, J. P.; Adelstein, S. J. and Kassis, A. I. (1996), Tumor-targeting potential of radioiodinated iododeoxyuridine in bladder cancer. J. Nucl. Med., 37 : (2), 315-320.

Vandieren, E. B.; Vanlingen, A. P.; Roos, J. C. and Teule, G. J. J. (1994), The relevance of uptake and Intracellular Distribution for the Dosimetry of Auger and Beta-Emitting Radionuclides in Micrometastases, Radiat. Protect. Dos., 52 : (1-2), 391-394.

Wang, S. M.; Chern, J. W.; Yeh, M. Y.; Ng, J. C.; Tung, E. and Roffler, S. R. (1992), Spesific Activation of Glucuronide Prodrugs by Antibodytargeted Enzyme Conjugates for Cancer Therapy, Cancer Res., 52, 4484-4491.

Weinreich, R.; Wyer, L.; Crompton, N.; NievergeltEgido, M. C.; Guenther, I.; Roelcke, U.; Leenders, K. L. and Knust, E. J. (1998), I-124 and Its Applications in Nuclear Medicine and Biology, IAEA TECDOC1029. pp. 399-418.

Wiebe, L. I. (1998), Radiipharmaceuticals for Diagnosis and Therapy of Cancer, Modern Trends in Radiopharmaceuticals for Diagnosis and Therapy, IAEA TECDOC-1029. pp.513-519.

Winborn, W. B.; Sheridan, P. J. and McGill Jr., H. C. (1987), Sex steroid receptors in the stomach, liver, pancreas, and gastrointestinal track of baboon, Gastroenterology, 92 : (1), 23-32.

Yasui, L. S.; Hughes, A. and DeSombre, E. R. (1996), DNA Damage Induction by 125I-Estrogen, Acta Oncologica, 35 : (7), 841-847. 
Zalutsky, M. R. and Vaidyanathan, G. (2000), Astatine211-Labeled Radiotherapeutics: An emerging Approach to Targeted Alpha-Particle Radiotherapy, Curr. Pharm. Des., 6, 1433-1455.

Received: June 13, 2002;

Revised: June 17, 2002;

Accepted: June 19, 2002. 